\title{
Development of a Procedure to Maximize Production of Hardy Rootstocks of Citrus Using Stem Cuttings
}

\author{
Richard C. Beeson Jr. ${ }^{1 *}$, Dilma Silva² \\ ${ }^{1}$ University of Florida Institute of Food and Agricultural Science Mid-Florida Research and Education Center, Apopka, USA \\ ${ }^{2}$ Agromillora Florida, Inc., Wildwood, USA \\ Email: *rcbeeson@ufl.edu
}

How to cite this paper: Beeson Jr., R.C. and Silva, D. (2017) Development of a Procedure to Maximize Production of Hardy Rootstocks of Citrus Using Stem Cuttings. American Journal of Plant Sciences, 8, 2837-2846.

https://doi.org/10.4236/ajps.2017.811192

Received: September 30, 2017

Accepted: October 27, 2017

Published: October 30, 2017

Copyright $\odot 2017$ by authors and Scientific Research Publishing Inc. This work is licensed under the Creative Commons Attribution International License (CC BY 4.0).

http://creativecommons.org/licenses/by/4.0/

\begin{abstract}
Shoots of Citrus sp. Kuharske were used to develop protocols for rooting reportedly HLB resistance rootstocks under intermittent mist. Investigated were shoot maturity, nodes per cutting, leaves per cutting, effects of buds, auxin concentrations and auxin solvent. Shoot maturity was most influential for success, with cuttings taken below the first $30 \mathrm{~cm}$ of active terminal growth producing greater root generation. Use of a thickening agent (Natrosal) to dilute the commercial auxin was second most in importance for rooting success. Root mass increased with increasing number of leaves. Cutting stems between nodes or below the lowest bud were inconsequential. To produce maximum number of viable cuttings, single node-single leaf cuttings were preferred. Single bud cuttings produced one shoot after rooting. This was adventitious since multi-node cuttings usually sprouted new shoots that would need to be removed before budded. Evaluation of the best combination of auxin and cutting-related attributes were evaluated with four additional common rootstocks in June 2016. Rooting was $100 \%$ successful. A quick dip (0.5 s) in a $7500 \mathrm{ppm}$ solution of Dip\&Gro produced the most root generation in six weeks for all rootstocks. Root quantity varied by rootstock.
\end{abstract}

\section{Keywords}

Citrus Propagation, Auxin Concentration, Stem Maturity, Cutting Length

\section{Introduction}

Florida's citrus industry has been devastated by Huanglongbing (HLB) disease, also known as citrus greening. Caused by the bacteria Candidatus liberibactera- 
siaticus [1], HLB is spread by Asian psyllids and progressively attacks and kills fine root. Up to $40 \%$ loss of fine roots occurs before symptoms in above ground portions of trees are noticeable. Infection leads to smaller fruit size and loss, significant yield loss, and over time dying and unproductive groves. Unfortunately, common citrus rootstocks used for decades are susceptible to HLB.

Controlling HLB requires advances in both tree health management and disease resistance. Screening, propagating, and producing disease resistant rootstock is fundamental to control. Fortunately, over the past several years vigorous and apparently disease-free shoots have been found on declining trees in dying groves. These shoots have been propagated in limited numbers, challenged repeated with HLB inoculation, and shown few to no signs of HLB infection [2]. While these selections have potential as rootstock, most are difficult to propagate by tissue culture and none produce viable seeds. Scions of these selections have been grafted onto common rootstocks for multiplicationvia vegetative cuttings to evaluate their potential as rootstock. How to root common citrus cuttings has been long known; how to economically root chimeras at a commercial scale has not.

Application of plant growth regulators, vegetative cutting age, and stem length has been shown to improve rooting, but not definitively and only on limited citrus germplasm. Propagation of citrus stem cuttings has a long history, dating back to the late1800's [3]. Since then there have been several reports on how auxin type, mixtures and concentration induce rooting of different varieties of citrus. As early as 1935 the rooting of lemon cuttings in coarse sand beds in sash covered propagation frames inside a glass greenhouse was described [4]. Temperatures were held around $30^{\circ} \mathrm{C}$ and cuttings were misted regularly. Cuttings of mature $15 \mathrm{~cm}$ long stems were treated with 1000, 2000 or $4000 \mathrm{ppm}$ Indole-acetic acid (IAA). The $2000 \mathrm{ppm}$ concentration was most effective in increasing rooting when a minimum of two mature leaves were retained, producing well-rooted plants without stem dieback. Stems treated with 1000 ppm produced little root mass and were similar to the water control. Naphthalene acetic acid (NAA) also improved root regeneration, but at half $(1000 \mathrm{ppm})$, the concentration required if using the Indo-butyricacid (IBA) [5]. All of these concentrations were applied using the 24 hour dilute soak method.

The use of intermittent mist for rooting citrus cuttings occurred in 1950 [5]. In 1999 [6] a procedure for rooting of cuttings from rootstocks of Carrizo and sour orange taken in September was reported. Cuttings of $20 \mathrm{~cm}$ in length (each containing 6 to 10 nodes) were taken from 1.5 year old trees. These were wounded, treated with $2500 \mathrm{ppm}$ of IBA in water and placed in vermiculite under mist for two months. Root mass, shoot mass and root length were greater for cuttings than comparable seed-grown plants. This was attributed to greater leaf area of cuttings, compared to seedlings of the same age, and could have been budded sooner. Auxin concentrations of 1000 and 3000 ppm IBA and NAA were evaluated on 12 selections of different Citrus genotypes [7]. Cuttings were placed 
under intermittent mist for 10 sec every 5 min during daylight. Success varied with auxin source and concentrations. The cultivar Carrizo rooted at $83 \%$ when treated with $3000 \mathrm{ppm}$ NAA, while similar concentrations of IBA only produced $67 \%$ success. Total root lengths six weeks after treatment initiation in late September were $36 \mathrm{~cm}$ with NAA and $24 \mathrm{~cm}$ with IBA. Six years earlier [8], trials containing IBA and NAA at $3000 \mathrm{ppm}$ stimulated the greatest root production in both juvenile and mature cuttings of Swingle citrumelo stems $15 \mathrm{~cm}$ in length, with three or four leaves rooted in the greatest numbers. More roots regenerated with IBA on juvenile cuttings, while mature cuttings produced more roots with NAA. In 2011 [9] node stem cuttings treated with 2500 ppm IAA in water produced more roots than lower concentrations (500 to $2000 \mathrm{ppm}$ ) and had higher success rates and growth. Here are presented the results of employing a commercial auxin mixture, it interacts with stem maturity for large-scale rooting of citrus stem cuttings. This was undertaken to enhance rooting the limited number of available potential HLB-resistant plant materials for evaluation in commercial groves. The research reported here evaluates a commercial mixture of IBA and NAA that has worked very well for rooting a wide range of woody ornamental plants [10], but has not been assessed for rooting of citrus. The objectives of this study were to:

1) Determine effect of shoot maturity on rooting of citrus stem cuttings.

2) Determine the optimum auxin carrier and auxin concentration for maximum rooting success.

3) Evaluate the best combination of stem maturity, auxin concentration on other common citrus rootstocks.

\section{Materials and Method}

\subsection{Effect of Stem Maturity on Rooting}

Two experiments were conducted to identify the most promising combinations of auxin concentrations, stem maturity and stem length using the citrus rootstock cultivar Kuharske. Kuharske originated China and Japan and is prized for its excellent control of burring nematodes. A third experiment was conducted to evaluate the best auxin treatment using other common rootstocks. In Experiment I, $60 \mathrm{~cm}$ shoots of young Kuharske rootstocks were harvested on 5 May 2015. These were cut into single node stems with one bud at either end and one leaf at the distal end. Six cuttings were made from each $30 \mathrm{~cm}$ stem. The proximal end of each cutting was quick-dipped $(0.5 \mathrm{sec})$ into one of eight auxin solutions (Table 2) before placement an in moistened cell tray (IP110, 45 cell trays, Stueve \& Sons, Tangent, OR) in a commercial substrate of $60 \%$ Canadian peat moss: $40 \%$ perlite (Fafard 2P, SunGro Horticulture, Agawam, MA). Auxin solutions of $0,4000,6000$ and 8000 ppm were derived by dilutions of a $15 \%$ commercial auxin source (Dip-n-Gro, Clackamas, OR, USA). Solutions were diluted either with de-ionized water or a solution ( $8 \mathrm{mg} / \mathrm{liter}$ ) of Natrosol (Natrosol250HBR PA, Ashland, Wilmington, DE). Natrosol is a food grade powder 
thickening agent. This was similar to the successful application of using Cell-u-wett (Hort Specialties Inc., Pinckney MI) for the rooting of western hemlock [11]. Cell-u-wett was not locatable when this experiment was initiated. Each treatment was replicated with 19 similar cuttings.

Trays were placed under an overhead mist system consisting of two mist nozzles (Dramm mist 360NW Green; Dramm Corp., Netherlands) spaced to uniformly cover $3.5 \mathrm{~m}^{2}$ of rooting trays. Mist timing and duration was controlled by a Sterling Controller 30 (Superior Controls, Torrance, CA). Mist was pulsed 15 seconds every 10 minutes from 6 am to $10 \mathrm{pm}$ EST from May to September. Five weeks after initiation, all cuttings were drenched a $150 \mathrm{ppm} \mathrm{N}$ of a commercial liquid fertilizer (20-10-20 Peters, Everris, Dublin, OH). Trays were left in the mist for 41 days, then harvested for measurements of new root and shoot mass. Dry mass was weighed to $0.1 \mathrm{mg}$ (MettlerAE100, Mettler Toledo, Columbus, $\mathrm{OH}$ ). Shoot growth was measured to the nearest $\mathrm{mm}$ using a ruler when available.

\subsection{Second Experiment}

In the second experiment, there were six cuttings classes, each treated with four levels of auxin concentrations. Cuttings were placed under mist as described above on 18 May 2015. The six classes of cuttings consisted to of two types of cuttings (Table 1), one type retain buds at both the proximal and distal ends of a cutting, retaining one bud more than the number of leaves. The other type had the proximal bud removed, such that leaf and bud number were the same. All cuttings were taken from Kuharske rootstocks below the first $30 \mathrm{~cm}$ of stem under shoot tips. Each cutting class was quick-dipped $(0.5 \mathrm{sec}$.) in one of four auxin solutions, $0,2500,5000$ and $7500 \mathrm{ppm}$ auxin. All auxin concentrations were prepared as described previously and diluted with the Natrosol solution. After treating the proximal end, each cutting was inserted into 45 cell seedling trays as in the first experiment and used the same substrate described above. Each of the 24 treatment combinations were replicated with three blocks of 12 cuttings per treatment. Misting periods and duration were the same as described for Experiment I. Cuttings in this experiment were harvested on 16 July 2015, 41 days after initiation. All cuttings were gently removed from the seedling trays, then washed

Table 1. Description of types of cuttings.

\begin{tabular}{ll}
\hline Class & Description \\
\hline 1 & 2 nodes, with 2 leaves, cut between nodes at the bottom 1 leaf cut between nodes at the bottom of a stem \\
2 & 3 nodes, with 3 leaves, cut between nodes at the bottom \\
3 & 2 nodes, with 2 leaves, cut just below the bottom node \\
4 & 3 nodes, with 3 leaves, cut just below the bottom node \\
5 & 4 nodes, with 4 leaves, cut just below the bottom node
\end{tabular}


and dried as described in the first experiment.

\subsection{Third Experiment}

The third experiment focused on replicating previous results with different of citrus rootstock cultivars, focusing on the two auxin concentrations of 4000 and 7500 ppm Dip\&Gro. In February 2016, rootstocks of Kuharski, Swindle 13, C-35, C54 and USDA 813 were obtained and transplanted into $27 \mathrm{~L}$ containers using the same commercial blend of 60:40 Canadian peat: perlite (Sun-Gro Horticulture). Trees were fertilized, irrigated and pruned lightly as needed to promote multiple shoots for cuttings. On 10 June 2016, 33 shoots of mature wood from each cultivar, comprised of three replications of 11 cuttings of each rootstock, were collected across several plants per rootstock. Shoots were converted to single node cuttings as described previously and treated with either 4000 or 7500 ppm Dip\&Gro and placed under mist. Cuttings were single node with one leaf and one bud at the distal end. This experiment began on 10 June 2016, with harvest on 21 July 2016, lasting 41 days.

These experiments were conducted in a sealed polycarbonate greenhouse with a double layer polyethylene roof from early May to late July in Florida. Two green house fans activated at $27 \mathrm{C}$, normally shortly after sunrise, and ran continuously until several hours after sunset. The greenhouse was equipped with a fine mesh screen $\left(16 \mathrm{~m}^{2}\right)$ on the north end for air movement and exclusion of small insects. Maximum temperatures were commonly 38C or higher most of the day. During this experimental period, daylight to dusk was around 14 hours.

\subsection{Statistical Analysis}

All data was analyzed using SAS 9.1.

\section{Experiment I.}

The experiment was arranged as a $2 \times 4 \times 2$ factorial design with 2 diluents as the main factor; deionized water and a solution of Natrosol, with 4 auxin concentrations as the sub-factor $(0,4000,6000$ and $8000 \mathrm{ppm})$ and 2 levels of stem maturity (immature and mature stems) as the sub-sub factor, with a total of 320 experimental units. Statistical analyses root dry mass, shoot length and rooting percentage were analyzed using GLM.

\section{Experiment II.}

Data was analyzed as a $6 \times 4$ factorial design with three blocks of 13 replications per treatment. There were 6 combinations of number of buds and leaves retained on a cutting. Sub-factors consisted of 4auxin concentrations $(0,2500$, 5000 and $7500 \mathrm{ppm}$ ), with a total of 23 experimental units. Data collected consisted of root dry mass, new shoot elongation and number of new shoots.

\section{Experiment III.}

Data was analyzed separately by cultivar as a one-way ANOVA with two 2 concentrations of auxin with 3 blocks of 10 replications each. Each rootstock analyzed separately. Data consisted of both root and shoot dry mass. 


\section{Results}

\subsection{Auxin Carriers (Experiment I)}

Root dry mass was recovered from all 16 sets of cuttings for Kuharske (Table 1). With distilled water as the solvent, root mass was greatest $(\mathrm{P}<0.05)$ with 4000 ppm auxin with cuttings taken from the oldest or lower $30 \mathrm{~cm}$ of stem (30 to 60 $\mathrm{cm})$. Cuttings made from the upper or youngest $30 \mathrm{~cm}$ of stem $(0$ to $30 \mathrm{~cm})$ produced greatest root mass at $6000 \mathrm{ppm}$. Younger stems produced less root mass $(\mathrm{P}<0.05)$ than the older stems. Using only Natrosol and no auxin doubled root dry mass compared to water alone, but absolute success was very low. The addition of auxin with the thickening agent had no effect on generated root mass, independent of auxin concentration.

Shoot growth occurring 41 days after initiation was exceedingly small for most treatment combinations (Table 2). The greatest growth always occurred from cuttings collected from the lower $30 \mathrm{~cm}$ of stem. Of these, the addition of $\mathrm{Na}-$ trosol alone or Natrosol with $8000 \mathrm{ppm}$ auxin, averaged shoots of $1.5 \mathrm{~cm}$ or longer. Other combinations averaged $0.3 \mathrm{~cm}$ to no shoot growth.

\subsection{Leaf Node and Bud Quantity Effect on Root and Shoot Growth (Experiment II)}

The second experiment evaluated the effect of the number of nodes with leaves, and their impact on rooting relating to whether cuttings should be cut with leaf

Table 2. Effects of auxin diluent, auxin concentration and stem maturity on root growth and shoot growth of Citrus sp. Kuharske. Each mean is represents 19 replications. Mean with the letter are not significantly diffident at the 0.05 percent level.

\begin{tabular}{|c|c|c|c|c|c|}
\hline Thickening agent & Auxin conc. (ppm) & Stem maturity & Root dry mass (g) & Shoot length $(\mathrm{cm})$ & Rooting percent \\
\hline $\mathrm{H}_{2} \mathrm{O}$ & 0 & $0-12^{\prime \prime}$ & $46.4 \mathrm{f}$ & $0 \mathrm{f}$ & 0 \\
\hline $\mathrm{H}_{2} \mathrm{O}$ & 0 & $12-24 "$ & $58.3 \mathrm{f}$ & $0.54 \mathrm{def}$ & 10 \\
\hline $\mathrm{H}_{2} \mathrm{O}$ & 4000 & $0-12^{\prime \prime}$ & $88.8 \mathrm{cde}$ & 0.09 ef & 70 \\
\hline $\mathrm{H}_{2} \mathrm{O}$ & 4000 & $12-24 "$ & $133.0 \mathrm{a}$ & $0.86 \mathrm{~cd}$ & 100 \\
\hline $\mathrm{H}_{2} \mathrm{O}$ & 6000 & $0-12 "$ & $101.7 \mathrm{bcd}$ & $0.15 \mathrm{ef}$ & 50 \\
\hline $\mathrm{H}_{2} \mathrm{O}$ & 6000 & $12-24 "$ & $112.0 \mathrm{abcd}$ & $0.44 \mathrm{def}$ & 70 \\
\hline $\mathrm{H}_{2} \mathrm{O}$ & 8000 & $0-12^{\prime \prime}$ & $68.4 \mathrm{ef}$ & $0.30 \mathrm{ef}$ & 70 \\
\hline $\mathrm{H}_{2} \mathrm{O}$ & 8000 & $12-24 "$ & $121.7 \mathrm{ab}$ & $1.55 \mathrm{ab}$ & 100 \\
\hline Natrosal & 0 & $0-12^{\prime \prime}$ & $101.9 \mathrm{bcd}$ & $0.22 \mathrm{ef}$ & 90 \\
\hline Natrosal & 0 & $12-24 "$ & $128.4 \mathrm{a}$ & $1.79 \mathrm{a}$ & 100 \\
\hline Natrosal & 4000 & $0-12 "$ & $97.2 \mathrm{bcd}$ & $0.20 \mathrm{ef}$ & 90 \\
\hline Natrosal & 4000 & $12-24 "$ & $110.7 \mathrm{abcd}$ & $1.14 \mathrm{bc}$ & 90 \\
\hline Natrosal & 6000 & $0-12 "$ & $96.3 \mathrm{bcd}$ & 0.07 ef & 90 \\
\hline Natrosal & 6000 & $12-24 "$ & $118.9 \mathrm{ab}$ & $0.59 \mathrm{de}$ & 100 \\
\hline Natrosal & 8000 & $0-12 "$ & $87.4 \mathrm{de}$ & $0.31 \mathrm{def}$ & 100 \\
\hline Natrosal & 8000 & $12-24^{\prime \prime}$ & $113.9 \mathrm{abc}$ & $1.55 \mathrm{ab}$ & 100 \\
\hline
\end{tabular}


buds at either ends or just the distal end (Table 1). All treatments, with exception of single node, single bud cuttings not treated with auxin, produced $100 \%$ rooting (Table 3). It is worth noting that some untreated cuttings also produced roots. Root dry mass generally increased as auxin concentrations increased within node treatments, and increased with an increase in the number buds. The greatest root dry mass change occurred when three leaves and four buds were quick-dipped in $7500 \mathrm{ppm}$ auxin. Reducing auxin concentration to $5000 \mathrm{ppm}$ with the same number of leaves and buds produced similar results. However, reducing auxin concentrations to $2500 \mathrm{ppm}$ reduced root dry weight by $11 \%$ when compared with the $7500 \mathrm{ppm}$ auxin. All other combinations produced root dry weight that was at least $26 \%$ lower than the most prolific node and bud combination.

Table 3. The effects of leaves and nodes on root dry mass, shoot growth and shoot number on cuttings of Citrus sp. Kuharske. Each mean represents 38 replications. Means with the same letter are not significantly diffident at the 0.05 percent level.

\begin{tabular}{|c|c|c|c|c|}
\hline Treatment & Auxin conc. & Root dry mass (g) & New shoot length $(\mathrm{mm})$ & Number of shoots \\
\hline 1 node cut at stem & 0 & $0.166 \mathrm{gh}$ & $23.8 \mathrm{~lm}$ & $0.21 \mathrm{~h}$ \\
\hline 1 node cut at stem & 2500 & $0.174 \mathrm{fgh}$ & $70.8 \mathrm{efgh}$ & $0.89 \mathrm{def}$ \\
\hline 1 node cut at stem & 5000 & $0.182 \mathrm{fgh}$ & $12.6 \mathrm{~m}$ & $0.21 \mathrm{~h}$ \\
\hline 1 node cut at stem & 7500 & $0.140 \mathrm{gh}$ & $30.2 \mathrm{klm}$ & $0.53 \mathrm{~g}$ \\
\hline 2 node cut at stem & 0 & $0.150 \mathrm{gh}$ & $38.9 \mathrm{jklm}$ & $0.58 \mathrm{~g}$ \\
\hline 2 node cut at stem & 2500 & $0.288 \mathrm{~d}$ & 61.6 fghij & $0.79 \mathrm{efg}$ \\
\hline 2 node cut at stem & 5000 & $0252 \mathrm{de}$ & $86.3 \mathrm{cdef}$ & $0.95 \mathrm{def}$ \\
\hline 2 node cut at stem & 7500 & $0.262 \mathrm{de}$ & 80.9 cdefg & $1.03 \mathrm{cde}$ \\
\hline 3 node cut at stem & 0 & $0.295 \mathrm{~cd}$ & $100.6 \mathrm{abc}$ & $1.52 \mathrm{a}$ \\
\hline 3 node cut at stem & 2500 & $0.374 \mathrm{~b}$ & $68.6 \mathrm{efgh}$ & $1.16 \mathrm{bcd}$ \\
\hline 3 node cut at stem & 5000 & $0.373 \mathrm{~b}$ & $109.6 \mathrm{ab}$ & $1.5 \mathrm{a}$ \\
\hline 3 node cut at stem & 7500 & $0.367 \mathrm{~b}$ & $99.8 \mathrm{abc}$ & $1.29 \mathrm{abc}$ \\
\hline 1 node cut at node & 0 & $0.172 \mathrm{fgh}$ & 54.7 hijk & $0.71 \mathrm{fg}$ \\
\hline 1 node cut at node & 2500 & $0.131 \mathrm{~h}$ & $36.1 \mathrm{jklm}$ & $0.64 \mathrm{fg}$ \\
\hline 1 node cut at node & 5000 & $0.203 \mathrm{efg}$ & $46 \mathrm{ijkl}$ & $0.64 \mathrm{fg}$ \\
\hline 1 node cut at node & 7500 & $0.232 \mathrm{def}$ & 61.9 efghij & $0.71 \mathrm{fg}$ \\
\hline 2 node cut at node & 0 & $0.273 \mathrm{~cd}$ & 79.7 cdefg & $1 \cdot{ }_{16} \mathrm{bcd}$ \\
\hline 2 node cut at node & 2500 & $0.365 \mathrm{~b}$ & $113.7 \mathrm{a}$ & $1.38 \mathrm{ab}$ \\
\hline 2 node cut at node & 5000 & $0.377 \mathrm{~b}$ & 87.6 bcdef & $1.11 \mathrm{bcd}$ \\
\hline 2 node cut at node & 7500 & $0.356 \mathrm{cb}$ & 65.8 efghi & $1.05 \mathrm{cde}$ \\
\hline 3 node cut at node & 0 & $0.271 \mathrm{~d}$ & 48.9 hijk & $1.13 \mathrm{bcd}$ \\
\hline 3 node cut at node & 2500 & $0.453 \mathrm{a}$ & $97.1 \mathrm{abcd}$ & $1.47 \mathrm{a}$ \\
\hline 3 node cut at node & 5000 & $0.479 \mathrm{a}$ & $92.4 \mathrm{abcd}$ & $1.16 \mathrm{bcd}$ \\
\hline 3 node cut at node & 7500 & $0.510 \mathrm{a}$ & $100.7 \mathrm{abc}$ & $1.16 \mathrm{bcd}$ \\
\hline
\end{tabular}


Mean shoot growth ranged from $12 \mathrm{~mm}$ for single node, single bud cuttings treated with $5000 \mathrm{ppm}$ auxin, to $113 \mathrm{~mm}$ for two node, three bud cuttings treated with $2500 \mathrm{ppm}$ auxin. Of the 24 combinations of nodes and auxin concentrations, seven treatments produced similar shoot growth in late summer. All had at least three buds and all but one (three nodes, three buds) were treated with $2500 \mathrm{ppm}$ auxin. Shoot growth, however, was not uniform. Cuttings from both single nodes and two nodes cut between nodes, all averaged less than one shoot per cutting (Table 3). Three buds were required to average at least one new shoot per cutting within 41 days. This was satisfied by two nodes cut with three buds, or three nodes cut with three or four buds.

\subsection{Rootstock Growth Comparison (Experiment III)}

Mean root growth was higher with $7500 \mathrm{ppm}$ auxin for all cultivars, but was significantly different $(\mathrm{P}<0.05)$ from 4000 ppm for Kuharske, C35, and USDA 812. For C-54 and Swingle-13, root dry weight was similar among concentrations. Greatest root growth occurred with Swingle-13 at over $120 \mathrm{mg}$ of dry root mass, independent of auxin concentration. Cuttings of C-54 registered the lowest root growth at around 50 milligrams. Shoot dry mass consisted of the stem and leaf of the original cutting and any gain in mass not associated with roots over the 41 days of rooting. Kuharske had the largest mass at harvest for both auxin concentrations, followed by C-35. The rest were generally $100 \mathrm{mg}$ lighter at harvest. New shoots generated during the short rooting period were small, with greatest measured for C-54 at nearly $24 \mathrm{mg}$ dry weight. In contrast there was no new shoot growth for Swingle-13 when treated with $7500 \mathrm{pm}$ auxin, and less than 1 mg with $4000 \mathrm{ppm}$ auxin. Though not significant $(\mathrm{P}<0.05)$, there was a weak trend of greater new shoot growth occurring with cuttings treated with 4000 $\mathrm{ppm}$ auxin compared to $7500 \mathrm{ppm}$. Root to shoot ratios trended be higher when $7500 \mathrm{ppm}$ was used.

\section{Discussion}

The most prominent factor affecting root growth was stem maturity. Within each auxin concentration and carrier, cuttings taken below the first $30 \mathrm{~cm}$ of actively shoots produced more root and more shoot dry mass than those from the upper 30 centimeters. The exception was when cuttings were not treated with auxin and dipped only in distilled water, where some root generation occurred, but there were no differences in root mass.

Beyond stem maturity, effects of auxin carrier (distilled water or Natrosol) and auxin concentrations were entangled (Table 2). Overall greatest root mass occurred when using water as the carrier at $4000 \mathrm{ppm}$ auxin. This was similar to ( $P>0.05$ ) treating cuttings with no auxin, but using Natrosol as the carrier. However overall highest root masses were produced with 6000 or 8000 ppm independent of carrier. Using Natrosol as the carrier improved rooting percentage from 90 to 100 percent. This contrasted with using water as the carrier, which 
only produced rooting success above $70 \%$ with cuttings taken from the older, lower $30 \mathrm{~cm}$ stem.

Auxin type has been shown to have significant effect on rooting of citrus. IAA has rarely been used for citrus since it is rapidly metabolized [11]. In 1985 [8] it was reported that $3000 \mathrm{ppm}$ IBA was best for rooting juvenile cuttings, whereas mature cutting rooted better with $3000 \mathrm{ppm}$ NAA. In most cases, using NAA for citrus has increased root mass compared to IAA or IBA and required lower concentrations [7]. Dip\&Gro contains a mixture of 1 part NAA and 2 part IBA. IBA is chemically close the natural IAA and acts quickly to promote cell division, whereas NAA is chemically dissimilar, promoting longer cellular activity [12].

While almost always some roots generated regardless of treatment, this was not the case for shoot growth (Table 2). Treatment with water and no auxin produced no shoot growth on cuttings. All other combinations produced some new shoot growth during the six week rooting period. As with root generation, new shoot growth was also greater from the lower $30 \mathrm{~cm}$ of stem than the upper $30 \mathrm{~cm}$. Shoot growth was greatest with the 8000 and $4000 \mathrm{ppm}$ auxins treatments. Even with the lower 30 stem segment, shoot growth was reduced for both water and Natrosol with the 6000 ppm concentration.

In Experiment II, rooting success was near $100 \%$ for all cuttings. However, cutting type had significant effects on root mass, shoot length and number of shoots (Table 3). Auxin concentrations had little effect on root mass (Table 3). Except for Treatment 4, there were no differences $(\mathrm{P}>0.05)$ in root dry mass among auxin concentrations of 2500 to $7500 \mathrm{ppm}$ within cutting types. Where no auxin was applied, root mass was lower $(\mathrm{P}<0.05)$ than similar auxin-treated cutting, except for Treatments 1 and 4. Greatest root dry mass occurred from cuttings with four remaining leaves treated with any auxin concentration. The second highest root masses occurred on cuttings with three nodes either cut below the third node or between nodes. Both these cutting types retained three leaves. Previous research reported greater root generation when cutting retained a minimum of two mature leaves [4] [5] [8]. Root growth from cuttings with two nodes were larger $(\mathrm{P}<0.05)$ if cut between nodes, leaving several centimeters of stem tissue below the lowest bud. Cuttings of single nodes, cut between nodes, generally had the lowest root mass but rooting success was 100 percent.

Experiment III focused on two auxin concentrations and five rootstocks. Root generation was strong for all rootstocks. However relationships between cutting dry mass and new shoot elongation were poor. Amounts of root generation appear to be rootstock specific.

\section{Conclusion}

All citrus rootstocks evaluated here produced an abundance of new roots within six weeks when treated with $7500 \mathrm{ppm}$ Dip\&Gro diluted with a thickening agent during the spring to fall period. Natrosol, a commercial thickening agent used 
for human consumption, functioned well as the diluent, but is not commercially available for propagation. Over the past 20 years Cell-u-wett (ethylellulose), once marked by Grifflin Corp., has been used as a thickening agent for successful propagation of over 130 woody plant species for research and in plant propagation classes [10]. In 2016, a source of Cell-u-wett was discovered and is available (Hort Specialties Inc., Pinckney MI).

\section{Acknowledgements}

The authors of this paper would like to thank the Citrus Research and Development Foundation for their support of our research.

\section{References}

[1] Johnson, E.G., Wu, J., Bright, D.B. and Graham, J.H.(2014) Association of "Candidatus Liberibacter Asiaticus" Root Infection, but not Phloem Plugging with Root Loss on Huaglongbing-Affected Trees Prior to Appearance of Foliar Symptoms. Plant Pathology, 63, 290-298. https://doi.org/10.1111/ppa.12109

[2] Grosser, J.W. (2013) Personal Communication, 20 June 2013. Verbal Communication of Non-Published Results.

[3] Conger, O.H. (1889) Lemon Culture. Annual Report of the Secretary of the State Board of Michigan, 361-365.

[4] Cooper, W.C. (1940) Rooting Citrus Cuttings with Synthetic Growth-Substances. Proceedings of the Florida State Horticulture Society, 53, 174-177.

[5] Ochse, J.J. and Reark, J.B. (1950) The Propagation of Sub-Tropical Fruit Plants by Cuttings, A Progress Report. Proceedings of the Florida State Horticulture Society, 63, 248-251.

[6] Rieger, M. (1992) Growth, Gas Exchange, Water Uptake, and Drought Response of Seedling-and-Cutting Propagated Peach and Citrus Rootstocks. Journal of the American Society for Horticultural Science, 117, 834-840.

[7] Sabbah, S.M., Grosser, J.W., Chandler, J.L. and Louzada, E.S. (1991) The Effect of Growth Regulators on the Rooting of Stem Cuttings of Citrus, Related Genera and Intergeneric Somatic Hybrids. Proceedings of the Florida State Horticulture Society, 104, 188-191.

[8] Ferguson, J., Young, M. and Halvorson, J. (1985) The Propagation of Citrus Rootstocks by Stem Cuttings. Proceedings of the Florida State Horticulture Society, $\mathbf{9 8}$, 39-42.

[9] Seran, T.H. and Umadevi, T. (2011) Influence of Indole Acetic Acid (IAA) on the Establishment of Stem Cuttings in Lemon (Citrus limon L.). Journal of Agricultural Research, 49, 517-524.

[10] Beeson Jr., R.C. (2000) Putting the Speed Back in Quick-dip Auxin Application. SNA Research Conference, 45, 298-302.

[11] Foster, G.S., Campbell, R.K. and Adams, W.T. (1984) Heritability, Gain, and C Effects in Rooting of Western Hemlock Cuttings. Canadian Journal of Forest Research, 14, 628-638. https://doi.org/10.1139/x84-114

[12] Macht, D.I. and Grumbein, M.L. (1937) Influence of Indole Acetic, Indole Butyric, and Naphthalene Acetic Acids on Roots of Lupinus Albus Seedlings. American Journal of Botany, 24, 457-460. https://doi.org/10.2307/2436433 